\title{
MAE-USP AMPHORA COLLECTION: VESSELS AND INSCRIPTIONS
}

\author{
Pedro Paulo A. Funari*
}

FUNARI, P.P.A. MAE-USP amphora collection: vessels and inscriptions. Rev. do Museu de Arqueologia e Etnologia, São Paulo, 11: 275-282, 2001.

RESUMO: O Museu de Arqueologia e Etnologia da Universidade de São Paulo possui uma coleção de ânforas, com cinco selos e três peças anepigráficas. Após uma introduçạ̃o geral, há um catálogo de selos (quatro ródios e um de Cnido) e de ânforas (duas greco-itálicas e uma grega). $\mathrm{O}$ artigo concluise com um comentário sobre estas ânforas como evidência arqueológica.

UNITERMOS: Selos de ânforas - Rodes - Cnido - Ânforas greco-itálicas.

Amphorae were an important form of trade-packaging in the ancient world. They were used for transporting liquid commodities, usually wine, olive-oil and fish sauces. They were used first and foremost as containers for long distance commerce and supply. Amphorae provide us a direct witness of the movement of foodstuffs, important for both economic and cultural reasons. The study of these vessels is also made easier by the existence of a substantial body of epigraphic information, as many bear stamps impressed in the clay before firing and/or painted inscriptions written after firing (Peacock and Williams 1986: 2). Amphora, in Greek "a vessel for transport with two handles" (Funari 1987), was first in use in the Palestine in the fifteenth century B.C. The Canaanite jar travelled extensively outside the Palestine region, soon reaching Greece. The biconical form of the Canaanite

(*) Departamento de História do Instituto de Filosofia e Ciências Humanas da Universidade Estadual de Campinas. vessel was in use in the Minoan and Mycenaean periods but Greece did not adopt the typical amphora shape until the seventh century B.C.. Amphorae from different cities developed their own distinctive forms, permitting the easy recognition of their contents in the market (cf. Funari 1985a).

The handles of Greek amphorae were often stamped, referring to producing estates, names of ephors and months, being certificates of capacity, guarantee of weight of contents for both taxation and consumer information (Grace 1949). The evidence of the stamps indicates that amphorae from Rhodes and Knidos were exported from the homeland to the colonies and settlements around the Mediterranean basin. Greek settlement and trade in southern Italy and Sicily led to the development, around the later fourth and early third centuries B.C. of the so-called Greco-Italic amphorae (Will 1982). The fabric of most amphorae is coarse and mineral and rock inclusions are rife. Large vessels were usually built up in stages, smaller ones were produced as ordinary pottery. All the amphorae required to have its mouth 
sealed, being usual different stoppers, like cork or fired clay closures.

Amphora studies has been developing since the nineteenth century, most notably since the 1970s (Funari 1985b). The main specialised areas are classification and typology, petrography and epigraphy, usually of particular amphora types. The study of amphorae has been important for the economic and social interpretation of the ancient world, as they provide a plethora of data on the ancient economy, society, habits and culture. Amphorae provide unique information on such subjects as commodities movements and cultural habits, being directly linked to identity. Amphora studies have contributed to a better understanding of the ancient world (Garlan 1986:7), particularly through the publication of gazetteers of potteries (Empereur and Picon 1986), catalogues of inscriptions (Empereur 1982, Empereur and GuimierSorbets 1986, cf. Funari 1997: 85-86) and other efforts to publish and study corpora (Funari 1994). This way, it is possible to produce an informed analysis of ancient society: wirstschaftliche Prozesse sind nicht selten in eine nahezu naturgestzlische Rhetorik gekleidet worden. Was im Grunde erforderlich ist, ist eine soziale Geschichte der ökonomischen Sphäre, wie es die soziale Geschichte des 'sozialen' gibt (Wellkopp 1998: 182).

The aim of this paper is to produce a catalogue of amphorae and amphora stamps in the stores of the Museu de Arqueologia e Etnologia da Universidade de São Paulo. This Museum stores two Greco-Italic amphorae and a Greek one, as well as five stamps, four from Rhodes and one from Knidos.

\section{Stamps from Rhodes and Knidos}

Wine was an important commodity exchanged during the Hellenistic period (Grace 1961: 14) and Rhodian and Knidian wine were widely exported, as they were cheap. Wines from Rhodes and Knidos were important in several markets, being Knidian some $65 \%$ of the more than 40,000 amphora stamps found at Athens and Rhodian more than $85 \%$ of the 90,000 stamps found at Alexandria. At Delos, stamps from
Knidos are ubiquitous (more than $60 \%$ ) and those from Rhodes are not negligible (more than 20\%) (Grace 1952:517). They also reached Italian markets in large numbers. Most amphorae were probably unstamped and it is hard to know the proportion of stamped to unstamped amphorae. Usually, Rhodian and Knidian stamps bear two names, one referring to the owner and the other to an eponymous magistrate, dating the amphora and the wine. Rhodian amphorae usually bear two stamps, on the top of each handle, with the following data: a date given by the name of the eponymous magistrate (epi+ name in the genitive), name of the Rhodian month (after 275 B.C.), another name in the genitive, probably referring to the authorised manufacturer. The stamp is circular, with the symbol of the city, a rose, in its core, although sometimes it is rectangular, other images being also possibly present (Grace 1961: 12; Grace and Savvatianou -Petropoulakou 1970: 279, 293; Van der Werff 1977: 34; Debibour 1979: 271). Stamps from Knidos bear the name of a magistrate and of the authorised manufacturer (Grace 1961: 12). Stamps from the two cities change after 146 B.C., when the Romans introduce the names of two controlling officials (Grace 1961: 20).

\section{Catalogue of stamps}

1.E.........A

$\triangle \mathrm{A} \Lambda \mathrm{IOY}$

Size of the stamp: $5.0 \times 1.8 \mathrm{~cm}$.

Shape of the stamp: rectangular.

Fabric: buff.

Dating: after 275 B.C.

Number: MAE-USP 64/11.18, donated by the Italian government.

Producing area: Rhodes.

Find place: Italy.

Description of the shard: handle of a Rhodian amphora, the diameter of the rim is calculated to be $12.8 \mathrm{~cm}$ and the angle of the stamp in relation to the neck is 21 degrees (Fig. 1).

The reference to the Rhodian month $\delta \alpha \lambda ı \sigma$ in the genitive indicates that the stamp was procuce after 275 B.C., when months were introduced in the Rhodian amphorae.

\section{$2[\mathrm{~A}] \mathrm{PI} \Sigma[\mathrm{TO}] \mathrm{KA} \Lambda \mathrm{EY} \Sigma$}

Second mark: $P(1 \times 1 \mathrm{~cm})$

Size of the stamp: $3.2 \mathrm{~cm}$.

Shape of the stamp: circular.

Fabric: grey. 
FUNARI, P.P.A. MAE-USP amphora collection: vessels and inscriptions. Rev. do Museu de Arqueologia e Etnologia, São Paulo, 11: 275-282, 2001 .

Dating: beginning of the second century B.C.

Number: MAE-USP 64/11.32., donated by the Italian government.

Producing area: Rhodes.

Find place: Italy.

Description of the shard: handle of a Rhodian

amphora, the diameter of the rim is calculated to be
$11.6 \mathrm{~cm}$ and the angle of the handle in relation to the neck is 21 degrees (Fig. 2).

The stamp refers to a Rhodian manufacturer called Aristokles, who was active in the last fifty years before Roman rule, from 146 B.C., enabling us to date it in the first half of

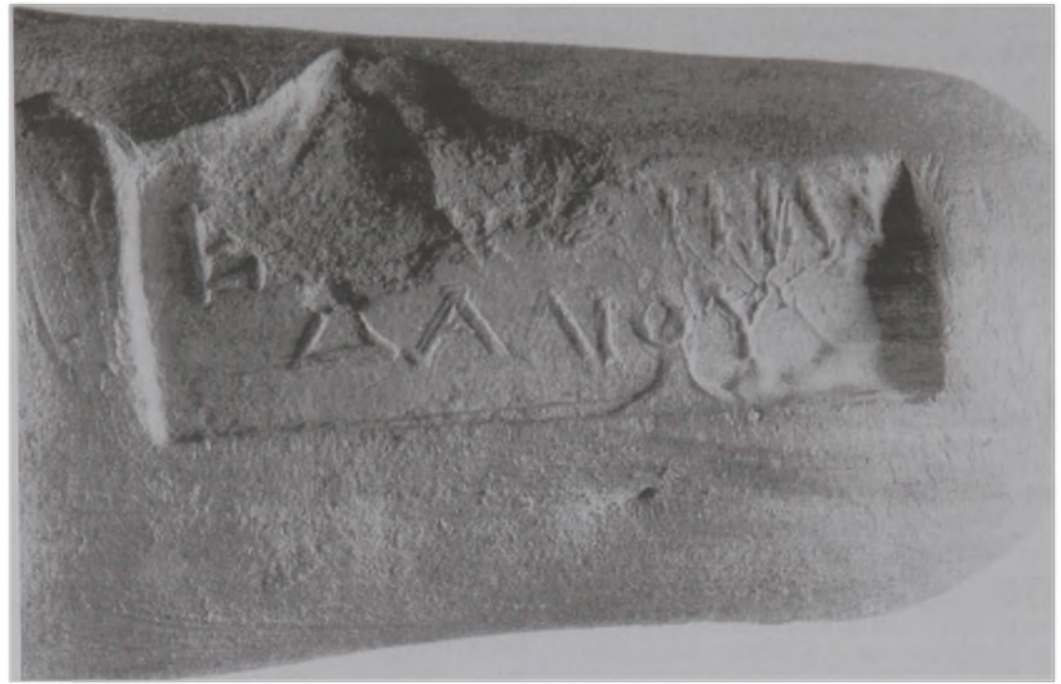

Fig. 1 .

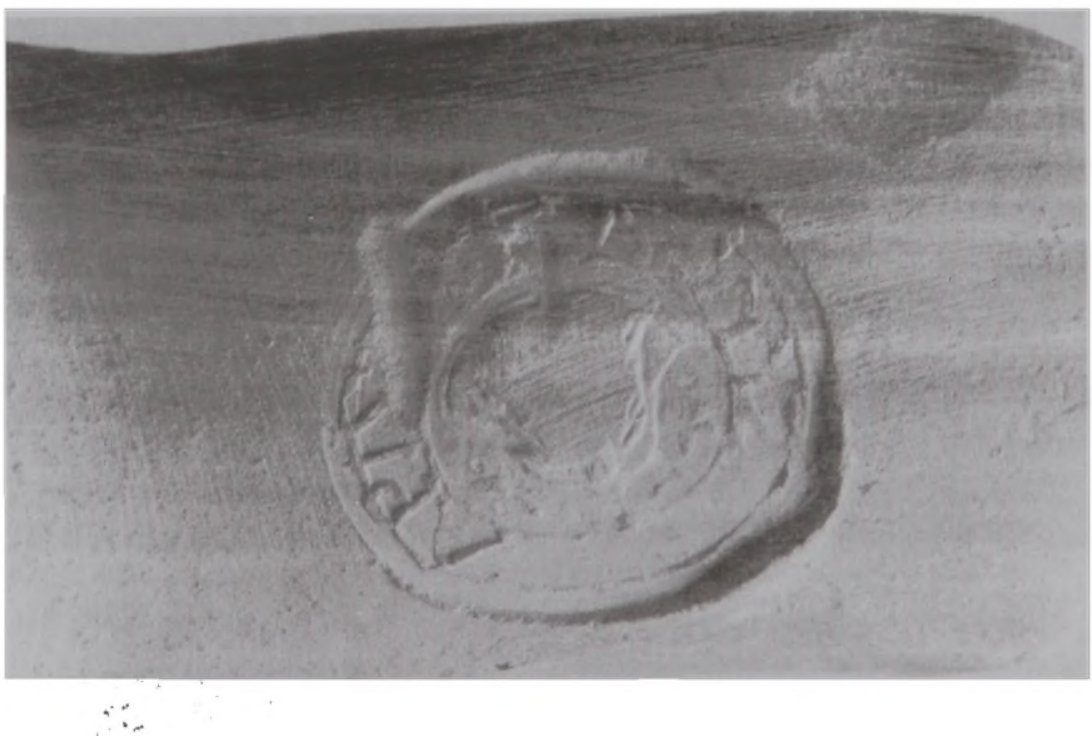

Fig. 2. 
FUNARI, P.P.A. MAE-USP amphora collection: vessels and inscriptions. Rev. do Museu de Arqueologia e Etnologia, São Paulo, 1I: 275-282, 2001.

the second century B.C. (Grace 1952: 526; Grace and Savvatianou-Petropulakou 1970:327).

\section{3. $[\Sigma] O[K P] A T E Y \Sigma$}

Size of the stamp: $3.4 \mathrm{~cm}$.

Shape of the stamp: circular.

Fabric: grey, whitened surface, reddish in core.

Dating: between 275 and 180 B.C.

Number: MAE-USP 75/1.41, donated by U.T.B

Meneses.

Producing area: Rhodes.

Find place: Delos.

Description of the shard: handle of a Rhodian amphora, the diameter of the rim is calculated to be $13.4 \mathrm{~cm}$ and the angle of the handle in relation to the neck is 15 degrees (Fig. 3).

We know two different Rhodian manufacturers called Sokrates, one active in the period between 275 and 180 B.C. and another one between 146 and the end of the second century B.C. Considering the angle of the handle, an earlier date is proposed (Grace 1952: 530; Grace and Savvatianou-Patropoulakou 1970: 302).

\section{4. ЕПІПРАТОФАN \\ ПANAMOY}

Size of the stamp: $3.9 \times 1.9 \mathrm{~cm}$.

Shape of the stamp: rectangular.

Fabric: grey, whitened surface, reddish in core.
Dating: between 220 and 180 B.C.

Number: MAE-USP 75/1.42, donated by U.T.B.

Meneses.

Producing area: Rhodes.

Find place: Delos.

Description of the shard: handle of a Rhodian amphora, the angle of the handle in relation to the neck being 11 degrees (Fig. 4).

A Rhodian manufacturer called Pratophanes is well known to be active between 220 and 180 B.C. (Grace 1952: 529; Grace and Savvatianou-Petropoulakou 1970: 294).

\section{AГAOINOY \\ KNI $\Delta$ IN \\ amphora}

Size of the stamp: $5.6 \times 1.6 \mathrm{~cm}$.

Shape of the stamp: rectangular, with a depiction of a Knidian amphora.

Fabric: red.

Dating: mid second century B.C.

Number: MAE-USP 75/1.43, donated by U.T.B.

Meneses.

Producing area: Knidos.

Find place: Delos.

Description of the shard: handle of a Knidian amphora, the angle of the handle in relation to the neck being 10 degrees (Fig. 5).

A manufacturer Agathinos is known to be active sometime before and after the Roman intervention in 146 B.C. (Grace 1952: 530; Grace and Savvatianou-Patropoulakou 1970: 294).

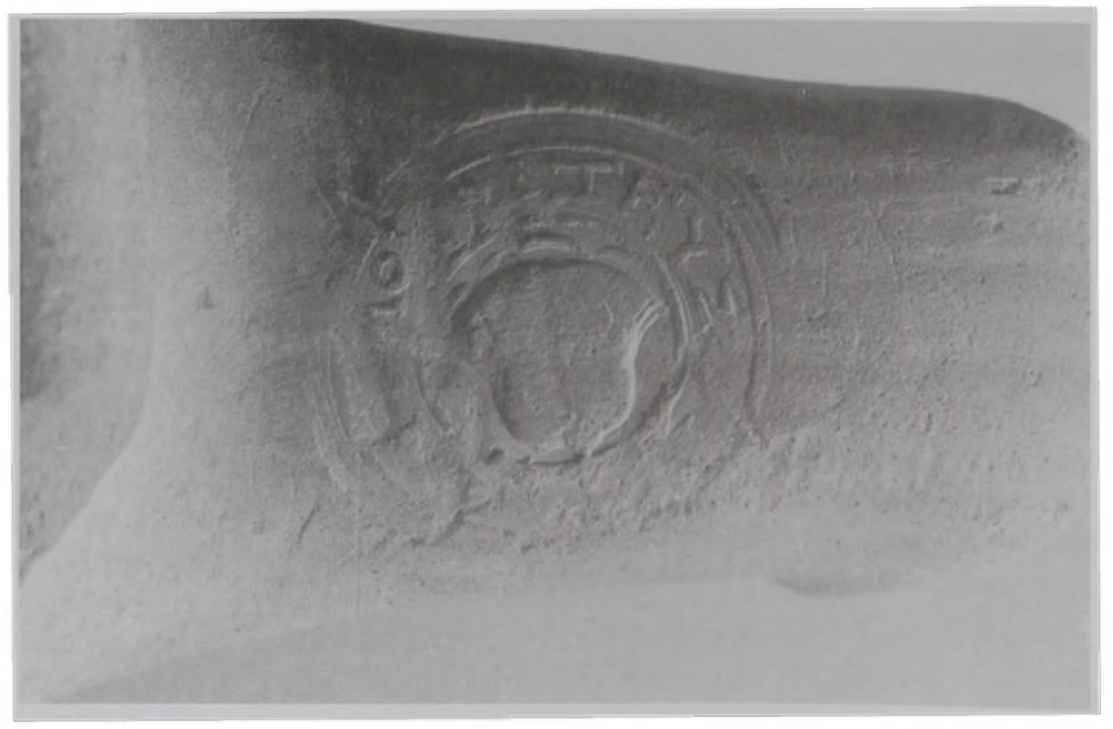

Fig. 3. 
FUNARI, P.P.A. MAE-USP amphora collection: vessels and inscriptions. Rev. do Museu de Arqueologia e Etnologia, São Paulo, 11: 275-282, 2001.

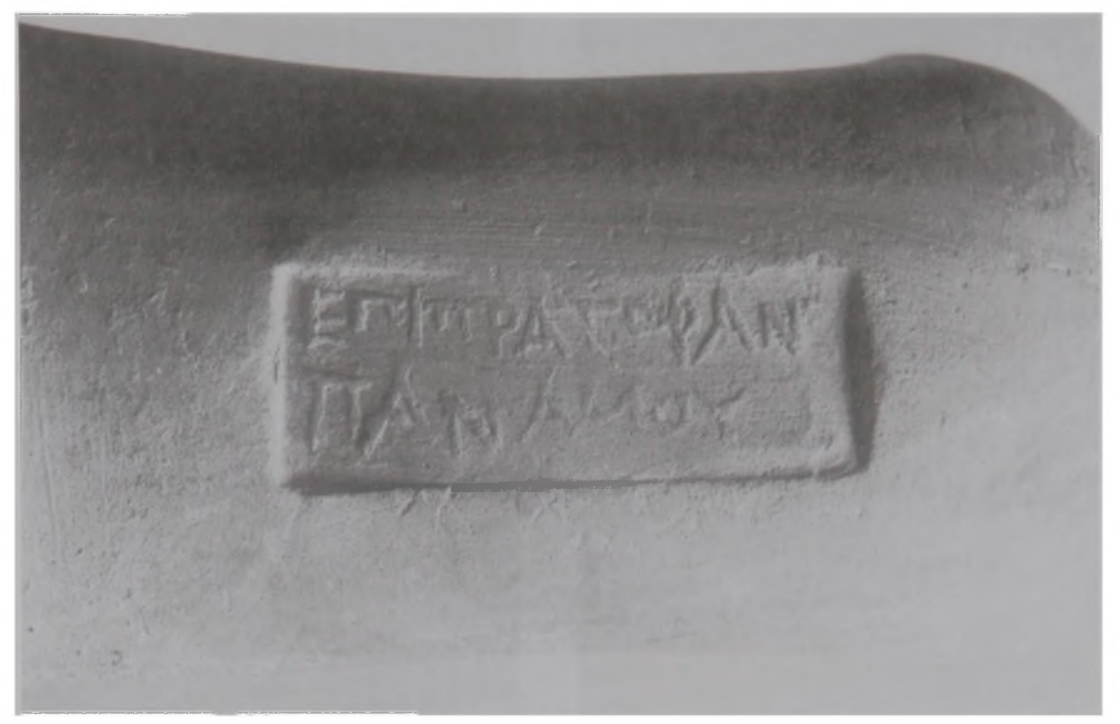

Fig. 4.

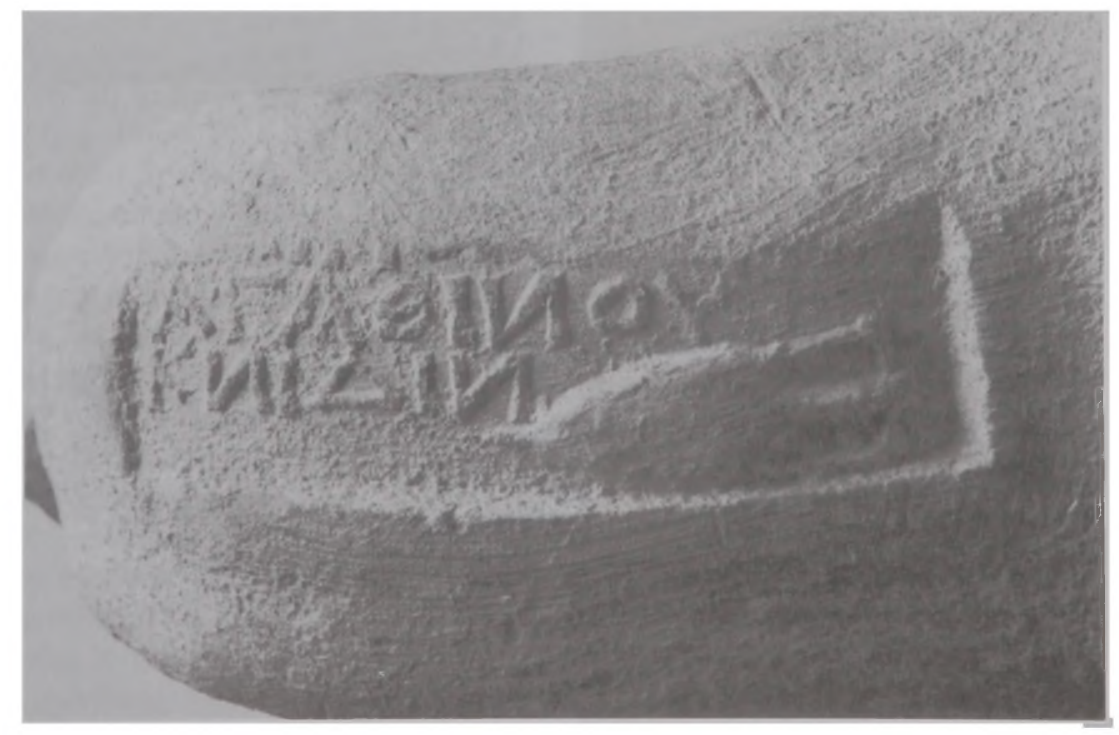

Fig. 5. 
FUNARI, P.P.A. MAE-USP amphora collection: vessels and inscriptions. Rev. do Museu de Arqueologia e Etnologia, São Paulo, 11: 275-282, 2001.

\section{Catalogue of wine amphorae}

\section{Graeco-Italic amphora}

Size: height, $40 \mathrm{~cm}$; rim diameter, $14 \mathrm{~cm}$; neck, 7 $\mathrm{cm}$, diameter, $8,5 \mathrm{~cm}$; body width, $21 \mathrm{~cm}$.

Shape of vessel: pear-shaped.

Fabric: grey.

Dating: $350-250$ B.C.

Number: MAE-USP 64/9.5, donated by the Italian government

Producing area: Italy.

Find place: Castiglioncello (Livorno, Italy).

Description of the vessel: triangular rim, cylindrical neck and carinated shoulder, ovoid handles are attached below the rim and on to the shoulders, body pearl-shaped and has a short solid spike (Fig. 6).

\section{Graeco-Italic amphora}

Size: height, $48 \mathrm{~cm}$; rim diameter, $12 \mathrm{~cm}$; neck, 12 $\mathrm{cm}$, diameter, $8,4 \mathrm{~cm}$; body width, $19.8 \mathrm{~cm}$. Shape of vessel: pear-shaped.

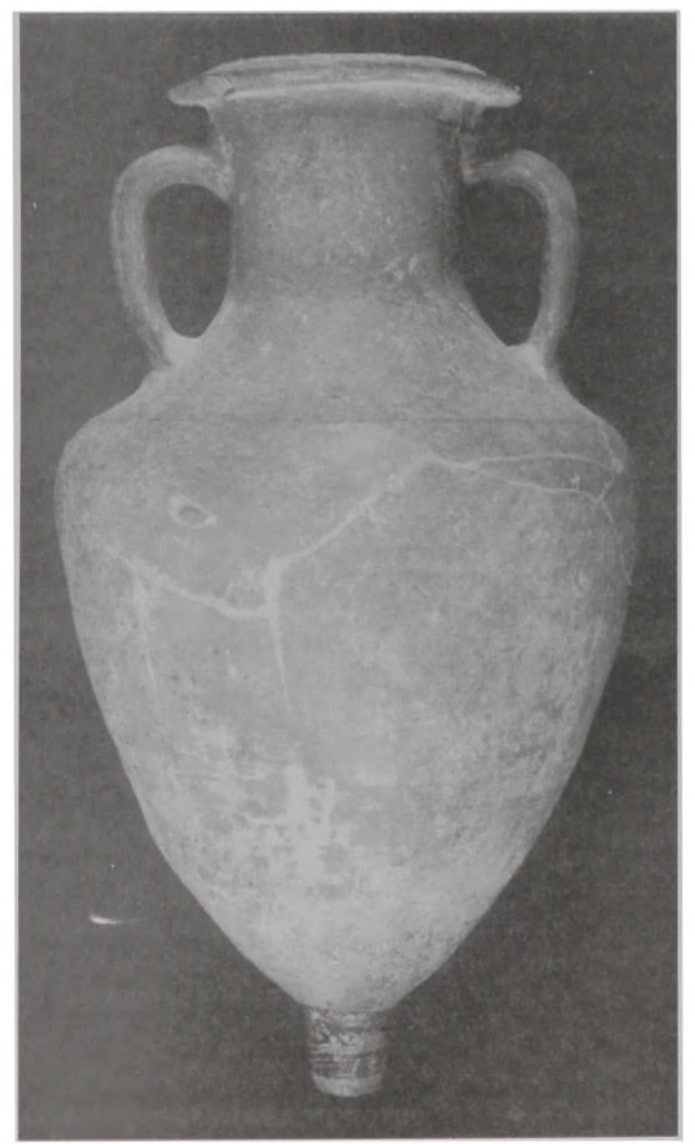

Fig. 6.
Fabric: buff.

Dating: $350-250$ B.C

Number: MAE-USP 64/9.6, donated by the Italian government.

Producing area: Italy.

Find place: Toscanella, Tumb of the Velinii (Italy). Description of the vessel: triangular rim, cylindrical neck and carinated shoulder, ovoid handles are attached below the rim and on to the shoulders, body pearl-shaped and has a short solid spike (Fig. 7).

\section{Greek amphora (fragment)}

Size: height, $69.5 \mathrm{~cm}$; neck diameter, $12 \mathrm{~cm}$; spike height, $10.5 \mathrm{~cm}$

Shape of vessel: cylindrical body.

Fabric: red.

Dating: fifth to fourth century B.C..

Number: MAE-USP 64/11.3, donated by the Italian government.

Producing area: Greece.

Find place: Palermo, Punic necropolis (Italy).

Description of the vessel: cylindrical body with a rounded shoulder and long, rod-like handles, and a short and stumpy spike (Fig. 8).

Graeco-Italic amphorae are also known as Republicaine 1, Lamboglia 4 and Peacock and Williams class 2 (Peacock and Williams 1986: 84-85; criticism of the term "Graeco-Italic" in Manacorda 1986). Graeco-Italic amphorae are at once Hellenistic Greek and Republican Roman and are the result of the coalescence of Roman and Hellenistic worlds and the sprout of mass markets. Objects of trade became standardised and the wine amphorae were produced in several Mediterranean areas during the period between the end of the fourth century B.C. until the mid second century B.C. (Will 1982). The two Graeco-Italic amphorae at the MAE-USP represent two different standards, even though both are within the range of the smaller containers.

\section{Conclusions}

The few amphorae and amphora stamps stored at the MAE-USP are a small sample of a most ubiquitous archaeological artefact found in the Mediterranean. The stamps are from Greek cities and are clear evidence of the importance, during late Hellenistic times, of municipal control of the production and trade in wine. They also reveal the 
FUNARI, P.P.A. MAE-USP amphora collection: vessels and inscriptions. Rev. do Museu de Arqueologia e Etnologia, São Paulo, 11: 275-282, 2001.

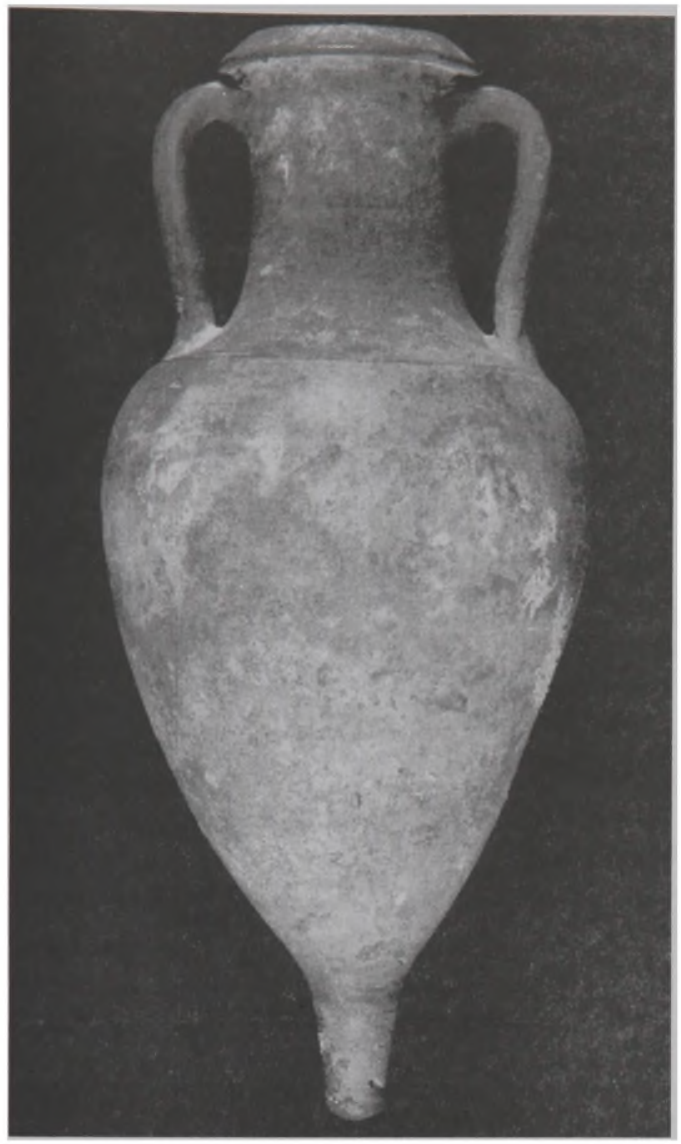

Fig. 7.

continuing importance of city state institutions until the Roman intervention in 146 B.C. The Greek style amphora in a Punic context is an indication that despite rivalries, wine trade was, since earlier times, putting in contact different peoples. The so-called pan-Mediterranean Graeco-Italic amphorae represent a new phase in the development of trade and manufacture, as they were produced in several areas scattered around the large Mediterranean basin, containing standardised volumes of supposedly similar quality wines. They bear witness to economic, social and cultural

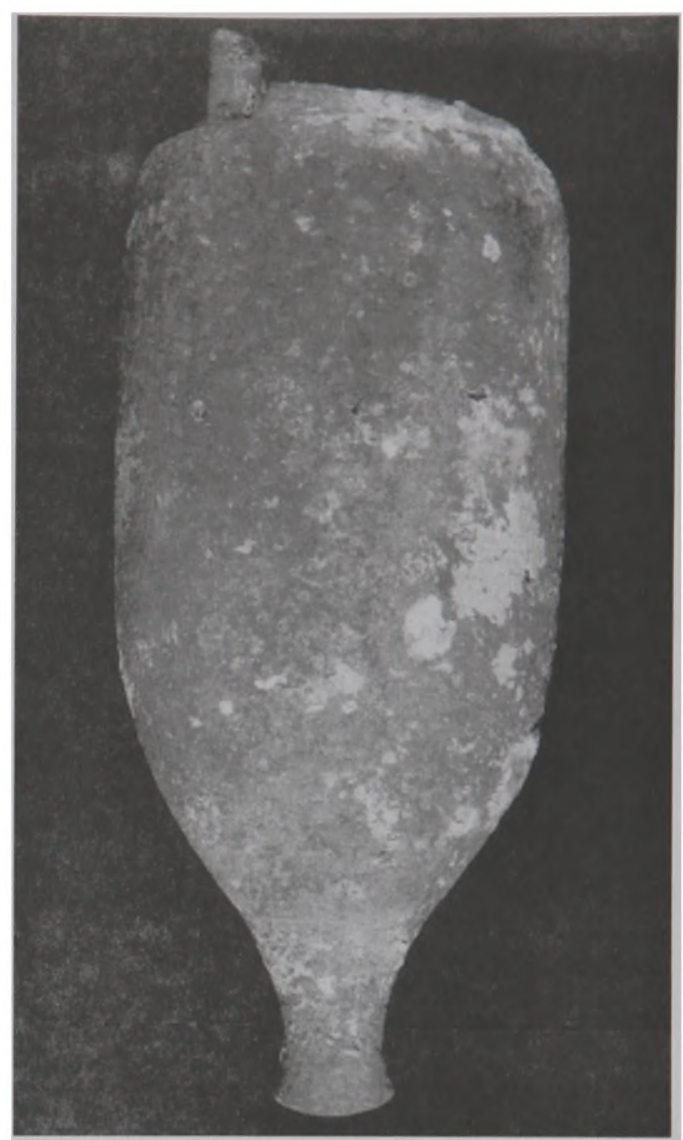

Fig. 8.

changes in the Mediterranean and by their materiality these amphorae are odd evidence of the social life in the ancient world.

\section{Acknowledgments}

I owe thanks to the following colleagues: Jean-Yves Empereur, Haiganuch Sarian, J.A. Van der Werff, Elizabeth Lyding Will, David Williams, as well as to Célia Maria Cristina de Martini. The ideas presented here are my own and for which I alone am therefore responsible. 
FUNARI, P.P.A. MAE-USP amphora collection: vessels and inscriptions. Rev. do Museu de Arqueologia e Etnologia, São Paulo, 11: 275-282, 2001.

FUNARI, P.P.A. MAE-USP amphora collection: vessels and inscriptions. Rev. do Museu de Arqueologia e Etnologia, São Paulo, 11: 275-282, 2001.

ABSTRACT: The Museu de Arqueologia e Etnologia of the São Paulo University has an amphora collection of five amphora stamps and three amphorae. After a general introduction, there is a catalogue of stamps (four Rhodian and one Knidian) and amphorae (two Graeco-Italic and a Greek one). The paper concludes with a comment on these amphorae as archaeological evidence.

UNITERMS: Amphorae stamps - Rhodes - Knidos - Graeco-Italic amphorae.

\section{References}

DEBIDOUR, M.

1979 Reflexions sur les timbres amphoriques thasiens. Thasiaca Suppl., 5: 269-314.

EMPEREUR, J.-Y.

1982 Les anses d'amphores timbrées et les amphores: aspects quantitatifs. Bulletin de Correspondence Héllenique 106: 219233.

EMPEREUR, J.-Y.; GARLAN, Y.

1986 Une banque de données sur les vases conteneurs - amphores et lagynoi - dans le monde grec et romain. J.-Y. Empereur; Y. Garlan (Eds.) Recherches sur les amphores grecques. De Boccard, Paris: 127-141.

EMPEREUR, J.-Y.; PICON, M.

1986 À la recherche des fours d'amphores. .J-Y. Empereur; Y. Garlan (Eds.) Recherches sur les amphores grecques. De Boccard, Paris: 103-126.

FUNARI, P.P.A.

1985a As transformações das ânforas oleárias béticas de tipo Dressel 20. Universidade de São Paulo, master's thesis.

1985b A Anforologia - uma nova disciplina arqueológica. Revista de História, 118: 161-170.

1987 Em torno da ânfora: a terminologia latina dos vasos recipientes. N. F. Pinto; J.L. Brandão (Eds.) Cultura Clássica em Debate. UFMG/CNPq/SBEC, Belo Horizonte: 51-61.

1994 L'huile et l'économie de la Bretagne romaine. P. Lévêque; J.A. Dabdab Trabulsi; S. Carvalho (Eds.) Recherches Brésiliennes. Belles Lettres, Bésançon: 95115.

1995 Dressel 20 inscriptions from Britain and the consumption of Spanish olive oil, with a catalogue of stamps. BAR, Oxford.
GARLAN, Y.

1985 Introduction au colloque. J.-Y. Empereur; Y. Garlan (Eds.) Recherches sur les amphores grecques. De Boccard, Paris: 3-8.

GRACE, V.

1949 Standard pottery containers of the ancient Greek world. Hesperia Suppl., 8: 175-189.

1952 Timbres amphoriques trouvés à Delos. Bulletin de Correspondence Héllenique, 76: 514-540.

1961 Amphorae and the Ancient Wine Trade. American School of Classical Studies at Athens, Princeton.

GRACE, V.; SAVVATIANOU-PETROPOULAKOU, M

1970 Les timbres amphoriques grecs. Exploration archéologique de Délos, 27: 277. 382.

MANACORDA, D.

1986 A proposito delle cosidette "grecoitaliche": una breve nota. J.-Y. Empereur; Y. Garlan (Eds.) Recherches sur les amphores grecques. De Boccard, Paris: 581-586.

PEACOCK, D.P.S.; WILLIAMS, D.F.

1986 Amphorae and the Roman Economy, An Introductory Guide. London: Longman.

VAN DER WERFF, J.A.

1977 Rhodian amphora stamps. Classical Antiquities in Utrecht: 34.

WELLKOPP, T.

1998 Die Sozialgeschichte der Vater, Grenzen und Perspektiven der historischen Sozialwissenschaft. Geschichte und Gesellschaft, 24: 173-198.

WILL, E.L.

1982 Greco-Italic amphoras. Hesperia, 52: 338-356. 